\title{
LAW, POLITY, AND THE REUNION OF THE CHURCH: THE EMERGING CONFLICT BETWEEN LAW AND THEOLOGY IN AMERICA
}

\author{
WILLIAM STRINGFELLOW*
}

\author{
I \\ LAW AND THE Churches IN AMERICA: \\ the presumption of Christian Disunity
}

The uneasiness in the churches in America about their division and disunity has reached a stage that portends crucial issues for the law. To anyone who does not believe in God, the guilt so evident among the churches because of their separation from each other must seem a bit ironical. The churches in the nation have never been more populated, more prosperous, more popular. ${ }^{1}$ The people have never been more inclined to support, whatever the reasons, a multiplicity of churches and sects and seances and religious sciences. ${ }^{2}$ The politicians and the legislators have never thought more positively, albeit never less critically, of religion, and "spiritual values," and even of the name of God. ${ }^{3}$

A. The Concern for Unity among the Churches

Though it appears that religious societies of almost any sort could survive and thrive at the present time, it is the churches which are the largest in communicant strength and the most important in economic resources and political influence and national status-those in a sense most able to survive on their own-who bespeak the most sober concern for the recovery of the unity of the Church.

The most publicized expression of that concern recently has been, of course, the call of Pope John XXIII for an Ecumenical Council to consider in some fashion not yet disclosed the separations between the Roman Church and other communions. The size and cohesion of the Roman Catholic Church in the United States makes the prospective deliberations of the Ecumenical Council of enormous significance to all the churches in America.

Even more recently, in conjunction with the celebration of the 450th anniversary of the birth of John Calvin, "Reformed and Presbyterian leaders over the world called ... f for a drive toward Christian unity that in time could end the separatism Calvin did so much to bring about." This appeal, which had the concurrence of American Presby-

* Member of the New York Bar; special counsel to the Episcopal Diocese of New York.

1 See Yearbook of American Churches for 1959 (Landis ed. 1958).

2 Massachusetts Council of Churches Study Group Draft Statement 4 (June 1957).

3 PfeFfer, The Case for Separation, in ReLIGION IN AMERICA 78 (1958).

4 N.Y. Times, June 1, 1959, p. 34, col. 4. 
terian leaders, was addressed to all the churches, Roman Catholic to Pentecostal, and apparently, therefore, contemplates conversations with churches which do not adhere to presbyterial polity.

Since the formation of the World Council of Churches, the Protestant, Anglican, and Orthodox member churches of the Council in the United States have been dealing with some of the specific issues of their disunity relating to both the doctrine of the faith and the government of the church. ${ }^{5}$

The last thirty years have witnessed a number of mergers of denominations, especially where divisions have been more a matter of sociology than either doctrine or polity. In 1931, for example, the Congregational Christian Churches were constituted of the Congregational Church, with its origins in Pilgrim New England, and the Christian Church, a denomination which began in the revivals of the late eighteenth century in the mid-west. ${ }^{6}$ In 1939, the Methodist Church, which like some other bodies had been divided in the Civil War, reunited. ${ }^{7}$ The Reformed Church in the United States and the Evangelical Synod of North America united as the Evangelical and Reformed Church in $1934 .{ }^{\circ}$

The concern among the major denominations for the reunion of the Church has been serious, but not always amiable. Where efforts toward union have attempted to deal with differences in ecclesiastical polity, the debilitating factionalism of Christian disunity has been exposed. Unmindful evidently of the admonition of the Apostle Paul that "to have law suits at all with one another is defeat for you," factions disputing polity have resorted to the civil courts to try to bar reunion. ${ }^{9}$ When the Congregational Christian Churches and the Evangelical and Reformed Church, both denominations the results of former mergers, negotiated a plan of union in spite of the differences in the polities of the two groups, a faction in the Congregational Christian denomination brought suit in New York to prevent the union. ${ }^{10}$

When the concern for unity is pressed with such seriousness that fundamental differences have to be faced, the temptation for the

5 See 1 Man's Disorder and God's Design 177-99 (1949). The most recent deliberations on the disunity of the churches in the United States took place in 1957 at the North American Conference on Faith and Order. The NAture of THE UNITY WE SEEK (Minear ed. 1958). The official reaction of the Central Committee of the World Council of Churches to the Ecumenical Council proposed by Pope John XXIII is reported in 18 Ecumenical Courier 1-2 (January-February 1959).

B Mead, Handbook of Denominations in the United States 73-77 (1956).

7 Id. at $145-52$.

SId. at $94-96$.

91 Corinthians $6: 7$.

10 See Cadman Memorial Congregational Society of Brooklyn v. Kenyon, 192 Misc. 124, 95 N.Y.S.2d 133 (Sup. Ct.), rev'd, 279 App. Div. 1015, 111 N.Y.S.2d 808, aff'd, 306 N.Y. 151, 116 N.E.2d 481 (1953). 
churches has been to look to the law to preserve their disunity. ${ }^{11}$

\section{B. The Historicity of American Law}

It is a common observation, as Leo Pfeffer says, "to note that the Constitution is a living document," which, along with the Bill of Rights, remains "viable and vigorous" because it "can be reinterpreted to meet the needs of contemporary generations." ${ }^{\text {" } 12}$ The same is essential to the maturity and wisdom of statutory law, especially, perhaps, where statutory law deals with matters closely related to constitutional provisions. Law needs to listen to history, not only to recollect what happened in the past, nor to enshrine the needs and prejudices of ancestors, but also to be responsive to contemporary life, and to esteem the present necessities. Where the law is static or abstract it becomes both obsolete and superstitious.

The laws of the states dealing with religious societies are under constraint to uphold the separation of church and state and the free exercise of religion. ${ }^{13}$ The conception of separation and religious liberty is rooted deeply in the history of early America and in the history of the multiplication of denominations in this country. Recalling both is essential to an appraisal of law and polity in the light of the renewed concern for the reunion of the Church. But the matter does not end there: the contemporary situation among the churches and the nature of the unity the churches seek, as well as the factions in society which have no church, must be taken into account.

\section{Law and Religious Pluralism in the Colonies}

In colonial America church and state were not separated. In the charter colonies in New England, which had substantial freedom in managing their internal affairs, the Congregational Churches became the legal establishment. ${ }^{14}$ The New England Puritans were perhaps most influenced in their principle of joinder of church and state by Calvin's plan for theocratic government in Geneva, but there was also the influence of the Anglican heritage. ${ }^{15}$

In the middle and southern colonies, which were managed by proprietary boards in England commissioned by the Crown, the established church was the Church of England. ${ }^{16}$ Yet there was no pretension of theocratic government in the Anglican establishment. Establishment just meant tax support of the church and the clergy. ${ }^{17}$ The view of some scholars is that the more liberal establishment in the colonies which had, paradoxically, the least political freedom from England, is attribut-

11 Ibid. See N.Y. Times, June 19, 1959, p. 14, col. 1.

12 PFEFFre, op. cit. supra note 3 , at 54.

13 Everson v. Board of Education, 330 U.S. 1 (1947).

14 SPERRY, ReLigIoN IN AMERICA 31-32 (1945) [hereinafter cited as SpERry].

$15 \mathrm{Id}$. at 33-34.

$16 \mathrm{Id}$. at 35 .

17 Ibid. cf. PFEFFER, op. cit. supra note 3, at 74-76. 
able mainly to economics. Dean Willard Sperry points out that when the influx of English settlers began to diminish, the proprietary colonies needed settlers regardless of their religious beliefs and recruited them from among persecuted sectarians on the Continent. ${ }^{18}$ In 1691, when Virginia sought a charter in England for the College of William and Mary, it was represented to the Lord of the Treasury that, just as Massachusetts had Harvard, Virginia needed a seminary for the training of ministers and the saving of souls. The Lord of the Treasury is reported to have replied, "Souls! Damn your souls; make tobacco."19 Somewhat later, in 1750, the issue arose in Virginia of the recognition of the Presbyterians in the colony. The established church opposed recognition, but the Lords of Trade in London told the Council of Virginia:

A free exercise of religion . . . is essential to ... enriching and improving a Trading Nation, it should ever be held sacred in His Majesties Colonies. We must therefore recommend it to your care, that nothing be done which can in the least affect that great point. ${ }^{20}$

The liberal establishment of Virginia and the theocracy of Massachusetts were the two chief precedents in church-state policy in the colonies, but the situation of those persecuted for religious belief or suffering civil disabilities because of religious dissent should be noted. Exiles, mainly non-conforming Puritans, from the charter colonies in New England founded the Naragansett Bay colony. ${ }^{21}$ And though they boasted of religious freedom, they had little toleration of Roman Catholics. ${ }^{22}$ Catholics migrated to Maryland, while the Quakers, who appear to have been the only ones who actually suffered execution for their beliefs, had their asylum in Pennsylvania. ${ }^{23}$

Economic necessity, diversity of nationality among the settlers, the multiplication of sects through migration and, because of persecution in the colonies, the emergence of indigenous nationalism in the Revolution - the entanglement of such factors as these set the stage for the separation of church and state in America.

D. Law and Religious Pluralism in the United States

By 1775 establishment was formally the case in three of the New England colonies, in four counties of New York and five southern colonies. The New England establishments were Congregational, the rest Anglican. ${ }^{24}$ Any attempt at a policy of establishment in the new

18 SPERRY 35.

10 Id. at 36.

$20 \mathrm{Id}$. at 37.

21 Id. at 33-34; see Mecklin, The Story of American Dissent (1934).

22 SPERRY 35-36.

${ }^{23} \mathrm{Id}$. at 38; see BERRY, The Society of Friends in America (Quakers) in The Aarerican Church of the Protestant Heritage 225-48 (Ferm ed. 1953).

24 SPERRY 50. 
nation could only have been advanced by one or the other of these churches, and neither was strong enough to prevail in that in the Congress. Neither would have agreed to recognize the other, anyway, it appears. ${ }^{25}$

Moreover, the sentiment against establishment was strong among the leaders in the making of the Constitution. George Washington was anxious that America "never again . . . see . . . religious disputes carried to such a pitch as to endanger the peace of society."26 Jefferson authored the Statute of Virginia for Religious Freedom, and its precedent in abolishing religious tests for public office was followed in the Constitution. ${ }^{27}$ Madison proposed the Bill of Rights with the First Amendment policy of no establishment and religious liberty. ${ }^{28}$

Though separation of church and state was the federal policy, with the adoption of the Bill of Rights, establishment remained in some states until 1833. Significantly, it expired then in Massachusetts because of schism between Congregationalists who confessed the Trinity and the Unitarians: the Trinitarians finally refused to pay taxes to support the schismatics. ${ }^{29}$

By the time the last vestages of establishment in the states had been ended, new forces were at work in the expansion and settlement of the nation which abetted the multiplication of denominations as, indeed, Madison anticipated when he said, "In a free government the security for religious rights consists in a multiplicity of sects."30 The definitive analysis of the forces spawning the fragmentation of the Church in America is The Social Sources of Denominationalism by H. Richard Niebuhr. Dr. Niebuhr points out these factors: (1) the stratification of the Church according to economic class and the control of property, (2) the impact of nationalism and of immigration dividing the Church in America according to foreign origin, (3) the significance of sectionalism at first in the conquest and settlement of the continent and later in the growth of provincialism and sectional churches, (4) the racial division and segregation of the churches. ${ }^{31}$

The interplay and the power of these influences in the multiplication of denominations in America are what, according to Dr. Niebuhr, the churches must confront in any serious search for unity.

The evil of denominationalism lies in the conditions which make the rise of sects desirable and necessary: in the failure of the churches to transcend the social conditions which fashion them into caste-organizations, to sublimate their

25 Ibid.

26 PFEFFER, op. cit. supra note 3 , at 60 .

27 Id. at 69 ; cf. SPERRY 44-45.

28 PFefFer, op. cit. supra note 3 , at 61 .

29 SPERRY 45-46.

$30 \mathrm{Id}$. at 54.

31 H. Richard Niebuhr, The Social Sources of Denominationalism (1957). 
loyalties to standards and institutions only remotely relevant if not contrary to the Christian ideal, to resist the temptation of making their own self-preservation and extension the primary object of their endeavor. ${ }^{32}$

Denominationalism represents, Dr. Niebuhr argues, "the moral failure of Christianity."

It would not be true to affirm that the denominations are not religious groups with religious purposes, but it is true that they represent the accommodation of religion to the caste system. They are emblems, therefore, of the victory of the world over the church, of the secularization of Christianity, of the church's sanction of that divisiveness which the church's gospel condemns. ${ }^{33}$

Calculations of the extent of denominationalism in the United States at the present time vary because of differences in reporting technique and the like, but by any calculation the separatism of the churches is staggering. Dr. Frank Mead figures that there are nearly $100,000,000$ members of 295,000 local churches in 266 distinct denominations and sects at the present time. ${ }^{34} \mathrm{Mr}$. Madison would, I suppose, be pleased, but the issue for the churches is that Saint Paul would be scandalized. ${ }^{35}$

\section{E. Law and Polity: Appeasement or Preference?}

The simplest interpretation of the American policy of separation and religious liberty is that such is the only practical accommodation that could be made to the diversity of churches when the Constitution and the Bill of Rights were adopted. And the obvious corollary to that is that the appeasement of denominationalism is extraordinarily more necessary today. Toleration is supposed to be the adjustment between pluralism and freedom in a democratic society. ${ }^{36}$ Neutralism is the guarantee of freedom of religion. Among a host of others, such was the observation of Lord Bryce:

It is accepted as an axiom by all Americans that civil power ought to be not only neutral and impartial as between different forms of faith, but ought to leave these matters entirely on one side, regarding them no more than it regards the artistic or literary pursuits of the citizens. There seems to be no two opinions on this subject in the United States. ${ }^{37}$

$32 I d$. at 21.

33 Id. at 25.

34 MEAD, op. cit. supra note 6, at 217-24. Another computation, using 1957 as the reporting year, computes over $104,000,000$ members of 306,893 congregations in 255 denominations. Yearbook of AMERICAN CHURChes For 1959288 (Landis ed. 1958).

35 See Ephesians 4:1-6; cf. Colossians 3:12-15, and Romans 12:3-8.

36 See Reinhold Niebuhr, $A$ Note on Pluralism, in Religion in America $42-50$ (1958).

372 Bryce, The American Commonwealth 766 (3d ed. 1894). 
American religious life and the policy of the law toward the churches, it is true, has been and, on the whole, is, as Dean Sperry describes it, "rankly individualistic."38 In his celebrated letter to the Danbury Baptists, Thomas Jefferson-who refused to join a churchwrote:

Believing with you that religion is a matter which lies solely between man and his God, that he owes account to none other for his faith or his worship, that the legislative powers of government reach actions only, and not opinions, I contemplate with sovereign reverence that act of the whole American people which declared that their legislature should "make no law respecting an establishment of religion, or prohibiting the free exercise thereof," thus building a wall of separation between church and state. ${ }^{39}$

But it is not supportable that this view is neutralism toward religious belief. It is, on the contrary, an article of the peculiar theology of Protestant dissent. It represents a preference in the law for a particular theology and, for that matter, for a specific polity. That is a polity which, I suggest, prizes disaffection and disunity in the churches, and the polity most gravely threatened by the prospect of the reunion of the Church. In short, a presumption in favor of Christian disunity is embodied in the law.

Mark De Wolfe Howe has said that the policy in the law of separation and religious freedom rests on theological presuppositions inconsistent with real neutrality among denominations.

Those who support the thesis that each man should be left free by government to follow the faith which his mind and heart prefer, very generally, if not invariably, have in religion, abandoned the belief that an ultimate truth has been revealed for all ... (this thesis) generally bespeaks a Protestant, and very frequently a skeptical, attitude toward the 'truths' of religion. ${ }^{40}$

Leo Pfeffer points out that the concept of separation and religious liberty united two forces in America, the same forces suggested by Howe as Protestant and skeptical, namely Protestant dissent and secular humanism. ${ }^{41} \mathrm{He}$ cites the advocacy of separation on theological grounds by Roger Williams, among several other early Baptist leaders. For example, John Leland of Virginia wrote that "government has no more to do with religious opinions of men than with the principles of mathe-

38 SPERRY 9.

39 Padoyer, The Complete Jefferson 518-19 (1943).

$40 \mathrm{KaTz}$, The Case for Religious Liberty, in ReLigion In America 113 (1958).

41 PFEFFER, op. cit. supra note 3, at 61 ; on the liaison of piety and secularism in democracy in America, see Reinhold Niebuhr, Pious and Secular America 1-13 (1958). 
matics," a statement which seems not to have been borne out either in the realm of religion or mathematics. ${ }^{42}$

That religion is a private affair, radically individualistic, is perhaps the singular affirmation of the churches of congregational polity in America. "According to the polity of Congregationalism (i.e. Independency), which was the pattern of church life in the New England colonies, any group of like-minded and professed believers have the right to organize themselves into a church," Dean Sperry observes. ${ }^{43}$ It is that very notion, basic to the polity of Protestant dissent, supported politically by the secular humanists, that is the rationalization of separation of church and state and of religious liberty. That notion in the law is theologically partisan, in spite of the gloss of neutrality in which it is sometimes defended. That is a notion, indeed, which encourages disunity in the Church. It is a notion that must be challenged insofar as the Church overcomes the "moral failure" of its denominationalism.

\section{II \\ Polity AND LAW: \\ the variations in denominational polities}

The separation of church and state in the United States does not mean, of course, a policy of absolute isolation of religion and government, either institutionally or substantively. As Professor Wilbur G. Katz has said, "In determining the limits of constitutional separation, it is the concept of religious freedom which provides the criterion. The principle of church-state separation is an instrumental principle." ${ }^{44}$ But separation does categorize the matters in which the law has any concern or contact with the churches. Generally the law professes no concern for the doctrines of churches, but it is frequently concerned with the government of the churches, with the polities of the denominations. ${ }^{45}$ The law supposes that theology and polity are severable.

A. The Polities of the Divided Church

Though the Church in the United States is divided as much as it is, most denominations and sects adhere to some variation of one of the three common polities-episcopal, presbyterial, or congregational. One study classifies ninety-nine groups with a congregational polity, seventynine with an episcopal government, and fifty-two with a presbyterial system, with four bodies which have a military type of organization, like the Salvation Army, and the remaining denominations either unclassified or, one suspects, unclassifiable. ${ }^{46}$ Population-wise, more

42 Pfeffer, op. cit. supra note 3 , at 63.

43 SPERry 9.

${ }^{44} \mathrm{KATZ}$, op. cit. supra note 40 , at 97.

45 Fiske v. Beatty, 120 Misc. 1, 198 N.Y. Supp. 358 (Spec. Term), aff'd as modified, 206 App. Div. 349, 201 N.Y. Supp. 441, aff'd, 238 N.Y. 598, 144 N.E. 907 (1924).

46 SPERRY 283-\$4. 
American church members belong to denominations governed according to episcopal polity than both congregational and presbyterial combined. ${ }^{47}$

In churches of episcopal polity, the Bishop is the primary governor of the church and guardian of its faith and discipline. In no instance, however, does the Bishop exercise absolute authority or unrestrained discretion:

[The Bishop] acts within a framework of doctrine and law that has been transmitted through the Church's life across the centuries, and it is his duty to adhere to the Church's teaching as he has received it. He is subject to the authority and discipline of his brother bishops, and to a pastoral relationship with his clergy and people which places important limitations on what he does and why he does it. ${ }^{48}$

Episcopal polity is found in a "constitutional" form in some churches in America in which a voice has been provided for laity and clergy in matters of doctrine and discipline. ${ }^{49}$ Among the principal churches with one form or another of episcopal polity in the United States are the Roman Catholic Church, the Eastern Orthodox churches, the Protestant Episcopal Church, the Old Catholic churches, the Polish National Catholic Church, the Methodist Church, and the Evangelical United Brethren Church. ${ }^{50}$

At the other extreme in polity are the denominations and sects of congregational or independent government, in which each individual congregation exercises authority in matters of doctrine and discipline. Each congregation is autonomous, but for practical administration of common concerns voluntary associations, or in some cases synods, of representatives of several congregations may exercise powers delegated to them. ${ }^{51}$ Among major groups with a congregational or a congregational-synodical form of government are the several Baptist bodies, the Congregational Christian Churches, the Disciples of Christ, some of the Lutheran churches, the Quakers and the Churches of Christ. ${ }^{52}$

The other common Christian polity is presbyterial, in which the church is governed by presbyters or elders, chosen from and approved by the members of the congregations, and the ordained ministry in representative bodies at several levels such as sessions, presbyteries, classes, synods, and assemblies. "The larger body or a representation of it exercises authority over the smaller, and the representation of the whole

47 Ibid.

${ }^{48}$ North American Conference on Faith and Order Document, Section 7, Authority and Freedom in Church Government 1 (Sept. 9, 1957).

49 Id. at 2.

50 SPERRY 284.

51 North American Conference on Faith and Order Document, Section 7, supra note 48 , at 2 .

52 SPERRY 283-84. 
exerts authority over all the parts." ${ }^{\text {"53 }}$ Denominations adhering to presbyterial polity, in addition, of course, to the several Presbyterian churches, include the Reformed Church in America, the Evangelical and Reformed Church, the Assemblies of God, some of the Lutheran churches, and the Christian Reformed Church. ${ }^{54}$

\section{B. Legal Recognition of a Variety of Polities}

Generally speaking the laws of the several states dealing with religious societies, and the courts of the states, recognize these various polities, although the statutes and the courts classify variations of polity in an ingenious number of ways. Ohio law rests upon distinction between churches with independent polity and those of connected polity, thereby recognizing that the episcopal and presbyterial polities are much more proximate to each other than either of them is to the congregational polity. ${ }^{\text {t5 }}$ If Ohio illustrates a jurisdiction with relatively simple classifications of polity for the purposes of statutory law, New York illustrates the opposite and contains in its Religious Corporation Law twenty-three different classifications to accommodate specific denominational requirements or the peculiar requirements of groups of denominations and sects with sufficient in common to warrant the same classification. ${ }^{\text {be }}$

The courts have tried to maintain that their recognition of various polities is their concern only insofar as the form of church government is related to the church or religious society as a legal entity dealing with "temporal" rather than so-called spiritual affairs. ${ }^{57}$ And in Harrison v. Hoyle, in which the court was called upon to determine the successor to property of the Ohio Yearly Meeting of the Society of Friends, after a factional dispute and schism among Ohio Quakers, the position was taken that civil courts in order to determine a property question will adopt the rules and enforce the polity of a denomination in the spirit and to the effect for which it was designed, and give effect to decisions of religious judicatories made in conformity with its own polity, provided that public policy is not thereby contravened. ${ }^{58}$

53 North American Conference on Faith and Order Document, Section 7, supra note 48 , at 2.

54 SPERRY 284.

55 OHIo Rev. Code $\$ 1715$ (1953).

56 N.Y. REL. CORP. LAW $\$ \$ 40-335$. Incorporation of church bodies was first authorized in New York in 1784. N.Y. Laws 1784, ch. 18. Soon, however, the policy of the legislature became that of providing especially for separate denominations, thus fitting the law to requirements of different polities. The first such enactment was for the Dutch Reformed Church. N.Y. Laws 1788, ch. 61, 11th session. The second concerned the Protestant Episcopal Church. N.Y. Laws 1795, ch. 25, 18th session.

57 Fiske v. Beatty, supra note 45.

5824 Ohio St. 254 (1873). 


\section{Politics and Polity}

It is readily acknowledged at least among theological scholars and religious sociologists that the polities of the American churches have evolved in part in response to "pressures characteristic of the American environment."

The episcopal, presbyterian, and the congregational forms have each been set forth as representing the original and ideal constitution of the Christian church. Yet the relationship of these forms to the political experience and desire of various groups is considerably more pertinent than is their relationship to the New Testament. Under the social and political conditions of the American frontier English presbyterianism, which had been convinced of its fidelity to the New Testament model, was almost unconsciously transformed into New England congregationalism, which now defended its form of organization as following the original and rightful Christian order. Episcopalianism was defended or attacked at many points in history, ostensibly because of its alleged maintenance of or departure from New Testament forms of church administration, but in reality because of its relationship to monarchical and absolute political government. ${ }^{60}$

Some denominations of congregational polity have rather boasted of the identity between their polity and their politics, in asserting that this polity represents democracy at its purest. ${ }^{61}$ And long after colonial times and disestablishment in some places the town meeting and the congregational meeting were the same event. ${ }^{62}$ The association of congregational polity with democratic politics may turn out to be a decisive issue in the quest for the reunion of the Church, for the most individualistic churches of this tradition are also those who renounce use of the historic Christian Creeds held in such esteem in the more orthodox Christian churches, and, in some instances, do not require Baptism. ${ }^{63}$ In that connection it is worth noting as well the identification of congregational polity and democracy in certain religious bodies in the United States which do not profess to belong to the Christian Church. ${ }^{64}$ Meanwhile, one Bishop of the Church of England has, with some

59 North American Conference on Faith and Order, Section 7, Orientation Paper of New York Study Group 7 (Sept. 1957).

$60 \mathrm{H}$. Richard NiebUHR, op. cit. supra note 31, at 14-15.

61 Deems, The Congregational Christian Churches, in The Aurerican Church of the Protestant Heritage 173 (Ferm ed. 1953). See Mitchell v. Church of Christ, 221 Ala. 315, 128 So. 781 (1930).

62 Petty v. Tooker, 21 N.Y. 267, 8 N.Y. Supp. 270 (1860).

$63 \mathrm{MEAD}$, op. cit. supra note 6, at 77.

64 Neither the Unitarian Church nor the Universalist Church in the United States adhere to the historic Christian Creeds. Edwin T. Buehrer, former editor of the Journal of Liberal Religion, suggests that the Unitarians are humanists, placing "their confidence in the power of the mind and their hope in the integrity 
hostility it is reported, concluded that "all the churches in America, whatever their polity, are congregational." 65

The good Bishop may have overstated the consequence of importing the principle of Protestant dissent into the law, of embodying a preference for independent or congregational polity in the law of separation and religious liberty.

On one hand, when, as Dr. Niebuhr warns, the denominations rationalize their politics in their polities, polity is apt to be divorced from the Gospel. But something like the reverse of that also takes place: polity becomes public policy. That is apt to mean the severance of polity from the Gospel, too.

\section{The Integrity of Polity in Theology}

Yet insofar as the unity of the Church is taken seriously, and inasmuch as the reunion of the Church is sought, polity must have its integrity in theology restored. The secularization of the Gospel一the relegation of polity to a mere gloss for political views and prejudices, the entanglement of polity with public policy-must be overcome if the Church is to recover unity. That is likely to require some radical changes in the denominations, and in the varieties of denominational polities, but then the reunion of the Church of Christ anticipates a very radical event.

The complaint of Dr. Niebuhr against polity as political rationalization is at the same time a plea for the fidelity of the Church to the Gospel, and he is among the first to point out that it is too simple and one-sided to consider that the several polities are utterly corrupted. ${ }^{66}$ Each of them retains some recollection of the Gospel and of the early Church, as well as of the history of the Church down through the centuries. ${ }^{67}$ Each maintains that the integrity of polity is in theology, that is, that both the definition and defense of polity is dependent upon theology. The way a church is governed and who governs a church is integral to the faith which a church confesses and represents in the world. At the Oberlin Faith and Order Conference it was said:

The episcopal polities are grounded in the conviction that episcopacy is of the esse of the church, and is so inextricably

of human personality." BURHRER, Unitarianism, in The AMERICAN ChURCh of the Protestant Heritage 159, 161-62 (Ferm ed. 1953). Unitarians identify their religious doctrine with the Arian heresy of the fourth century and Pelagianism of the early fifth century. BUEHRER, supra, at 150-51. Cf. Cummins, The Universalist Church of America, in The American Church of the Protestant HeritaGe 333-47 (Ferm ed. 1953). While these two religious movements have not participated in ecumenical discussions or negotiations among Christian bodies, they are presently preparing to merge with each other. See MEAD, op. cit. supra note 6 , at 200-02, 205-07.

05 SPERRY 9.

${ }^{66} \mathrm{H}$. RICHaRd NIEBUHR, op. cit. supra note 31 , at 13-14.

67 North American Conference on Faith and Order Document, Section 7, supra note 48 , at $2-5$. 
involved in its life and work as to constitute the nucleus, or heart, without which the whole would die and disintegrate. Polity is here a reflection of doctrine. A free-church polity, at least in the summaries presented to the committee, is regarded as pragmatic: one of several possible administrative structures, of indifferent confessional value per se, the selective principle being demonstrable utility in a given situation. This position is also doctrinal, possible only with a free-church ecclesiology, and the free-church polity, or rather the approach to polity is therefore also doctrinal. ${ }^{68}$

From the point of view of the concern for the reunion of the Church, and from the views of the churches, polity has its integrity in theology. The law speaks in a different language, disassociating, at least for certain purposes, polity and theology. Query whether that dichotomy can be maintained?

\section{III}

\section{LAW AND PoLITY:}

the policy of "multiple establishment"

The American law of separation of church and state and of freedom of religion represents, somewhat paradoxically, the insinuation of a particular confessional theology into public policy, and, at the same time, that public policy assumes that polity and theology are severable. Superficially, of course, the supposed dichotomy between polity and theology, reflected in court decisions and in statutes dealing with religious societies, sounds like it upholds the separation of state and church. Yet responsible ecumenical discussion in this country among the churches denies any dichotomy between polity and theology. ${ }^{69}$ Such a denial challenges anew the notion that the law is neutral toward religion; it exposes the law as still serving the requirements of the polity of Protestant dissent.

A. Disestablishment and the Incorporation of Churches

The meaning of the establishment of religion has changed since the First Amendment was drawn. Though there are reports that in some countries establishment is still associated with the suppression of non-conforming religious groups, that association no longer applies to England, from which the precedents for the colonial establishments were taken. Indeed, some leaders of the established church in England can be heard to complain that it is the only church there which suffers under civil disability for the reason that it is established. ${ }^{70}$

68 North American Conference on Faith and Order, Section 7, Orientation Paper of New York Study Group 8 (Sept. 1957).

69 The Nature of the UNity We SEEK 206-12 (Minear ed. 1958).

$70 \mathrm{On}$ the nineteenth century struggle over disestablishment of the Church of England, see Brose, Church and Parliament (1959). Disestablishment now appears to be a dead issue, but redefinition of Church-State relations continues, 
Not only does establishment nowadays carry no necessary association with restriction on religious freedom, but, it will be recalled, that the compatibility of the two was urged and to some extent practiced in colonial Virginia. ${ }^{71}$

Though both in the colonies and nowadays liberal establishments have been in effect, the Constitutional bar to establishment was given a strict interpretation. Madison vetoed a bill to incorporate the Protestant Episcopal Church in the District of Columbia, and said that it would violate the first amendment. "This particular church, therefore, would so far be a religious establishment by law, a legal force and sanction being given to certain articles of its constitution and administration."

Some states ostensibly follow Madison in considering incorporation of churches a form of establishment forbidden by the constitution. The Constitution of Virginia declares that the "General Assembly shall not grant a charter of incorporation to any church or religious denomi-

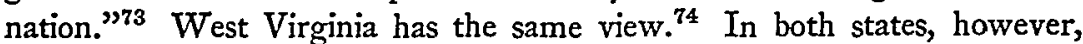
one suspects contrary to Mr. Madison's intentions, incorporation has been approved for religious purposes by the courts when a classification was proposed by the incorporators which could be distinguished, though ever so slightly, from "church or religious denomination." In 1885, Virginia incorporated the Protestant Episcopal Education Society, whose purpose was to provide for seminary training, thus incidentally correcting the preference of some for tobacco over a learned ministry, nearly two centuries earlier. ${ }^{75}$ West Virginia has held that a missionary society is not a church, and, therefore, can be incorporated. ${ }^{76}$ (Perhaps the real meaning of the severance of polity and theology is the opposite holding: a church is not a missionary society!) These decisions, plus the fact that the state constitutional prohibition of church or denomination corporations does not in itself inhibit work by a denomination incorporated elsewhere, means that the practical distinction between states forbidding and those permitting incorporation of a church are not substantial. ${ }^{77}$

for example, in the establishment of the Church Assembly by Act of Parliament in 1919 which gave the Church of England something like its own legislature. See NeILl, Anglicanism, 391-406 (1958) and The Report of the Archbishops' Committee on Church and State (1917).

71 See p. 415 and note 20 supra.

721 Richardson, Messages and Papers of the Presidents 489 (1900).

73 VA. CON5T. $\$ 59$ (1902).

74 W. VA. CONST. art. VI, $\S 47$ (1872).

75 Protestant Episcopal Education Society v. Churchmen's Representatives, 80 Va. 718 (1885).

76 Stump v. Sturm, 254 Fed. 535 (4th Cir. 1918). But see Powell v. Dawson, 45 W. Va. 780, 32 S.E. 214 (1899) (incorporation of Baptist missionary society would violate constitution), and of. Wilson v. Perry, 29 W. Va. 169, 1 S.E. 302 (1884) (Presbyterian Committee on Publications is not "church or religious denomination" prohibited from incorporation).

77 Trustees of the General Assembly of the Presbyterian Church in the 


\section{B. The Religious Corporation and the Churches}

Most of the states permit religious societies of several varietiescongregations, dioceses, synods and the like, missionary or educational societies, denominations-to incorporate or to create a corporation for the holding and management of property for religious uses, without evident anxiety that religious corporations are inconsistent with separation of church and state and the prescriptions against establishment of religion. In terms of recognition of the various common polities, the categorizations of state legislation, as has been hereinbefore noted, present no uniform pattern. ${ }^{78}$ At the same time, in several jurisdictions the decisions indicate that the grant of a corporate charter to a church by a state restricts its freedom to change polity, which usually means its denominational affliation, and to change its confession of faith, an issue to be examined presently. ${ }^{79}$

Apart from the effect of incorporation on situations of schism, the language of the courts develops the dual entities doctrine. As the court in one celebrated early New York case, Petty $v$. Tooker, put it:

These two bodies, viz: the corporation and the Church, although one may exist within the pale of the other, are in no respect correlative. The objects and interests of the one are moral and spiritual; the other deals exclusively with things temporal and material. ${ }^{80}$

Though Petty was eventually overruled on other grounds, the divisions between corporation and temporalities on one hand and church and spiritualities on the other is still fundamental to the law of religious corporations. In 1940, in Walker Memorial Baptist Church v. Saunders, the court reiterated the doctrine in New York, "In dealing with religious corporations, it is necessary to bear in mind that two separate entities are involved. One is the legal corporation; the other is the spiritual association of religious congregants which constitute the church itself." ${ }^{\text {"81 }}$ In Ohio, the same theory is advanced in Harrison v. Hoyle. ${ }^{82}$ In South Carolina, the court was more concrete, saying that a religious corpoation is simply a civil institution for the management of property. ${ }^{83}$

U.S. v. Gutherie, 86 Va. 125, 10 S.E. 318 (1889) (North Carolina religious corporation not barred from Virginia). The Virginia General Assembly is constitutionally authorized to provide for securing the title of any church property. VA. CoNsT. $\$ 59$ (1902).

78 See p. 421 supra.

79 See p. 421 supra.

8021 N.Y. $267,271,8$ N.Y. Supp. 270,271 (1860).

81173 Misc. 455, 457, 17 N.Y.S.2d 842, 844 (Sup. Ct. 1940). It was said in an early New York case that there are not two, but three entities involved: (1) the church or spiritual body of communicants and officiants, (2) the congregation of attendants at worship competent to vote, and (3) the trustees of the religious corporation. Lawyer v. Cipperly, 7 Paige Ch. 281 (N.Y. 1838).

82 Supra note 58.

83 Wilson v. Presbyterian Church, 2 Rich. Eq. 192 (S.C. 1842). 
When the separate entities doctrine was applied to a question of whether the members of the religious corporation had to be also members of the church which was "within the pale of" the corporation, in Fiske v. Beatty, the New York court ruled that such membership was not essential. ${ }^{84}$ And though this may seem on the face of it-to members of that church at least-a carrying of entities to extremes, there is a decision in New York ninety-two years prior to Fiske that holds that a person who has been expelled from a church may remain a trustee of the corporation associated with it. ${ }^{85}$

This doctrine of the two entities is used mainly, as one would expect, as a principle limiting the jurisdiction of the civil courts in litigation involving the churches. As the cases involving both schism in a church and merger of churches show, the courts accept jurisdiction where a question involving property rights or civil rights is involved. ${ }^{86}$ In doing so, however, the courts continually deal with issues of polity, not only of identifying the polity of a party before it, but of interpreting that polity, frequently, so as to give it the effect that its confessional presuppositions require. That happened, for example, in Immaculate Conception v. Murphy, where a Roman Catholic parish in Nebraska sought to restrain an excommunicated priest from exercising the office of priest and to restrain the trustees of the religious corporation from permitting him access to the parish property to do so. ${ }^{87} \mathrm{~A}$ closely related case involving an expelled minister gave Nebraska a chance to interpret a Protestant polity. ${ }^{88}$

C. Separation and the Establishment of Separatism

The author of the First Amendment policy of separation of church and state and religious liberty advocated a strict disestablishment, including denial of corporate charters to churches, but thought favorably of a multiplicity of sects and denominations. ${ }^{89}$

Yet in coping with the multiplication of churches in America, the laws of the states have found it or thought it necessary to depart from strict disestablishment far enough to authorize incorporation of churches and related religious bodies. That suggests that at some point independent polity becomes so individualistic that it degenerates from religious pluralism into religious anarchy, but it would be very speculative to impute that as a motive for the laws of religious corporation in the states. But those laws do represent a recognition of the common polities

s4 120 Misc. 1, 198 N.Y. Supp. 358 (Spec. Term) aff'd as modified, 206 App.

Div. 349, 201 N.Y. Supp. 441, aff'd, 238 N.Y. 598, 144 N.E. 907 (1924).

85 Baptist Church in Hartford v. Witherell, 3 Paige Ch. 296 (N.Y. 1832).

86 Baptist Church in Hartford v. Witherell, supra note 85 , at 301 . See

Watson v. Jones, 80 U.S. (13 Wall.) 679 (1872).

8789 Neb. 524, 131 N.W. 946 (1911); cf. St. Vincent's Parish v. Murphy,

83 Neb. 630, 120 N.W. 187 (1909).

88 Pounder v. Ash, 44 Neb. 672, 63 N.W. 48 (1895).

89 See p. 416 supra. 
among the denominations, something which Madison condemned as partial establishment, when the attempt was made to incorporate one of the denominations. The laws of the states on religious corporations move in the direction of "multiple establishment". Separation means the establishment of separatism.

What is lacking that has been the traditional characteristic of establishment in direct government financial support of religion, but in place of that, in addition to tax concessions and the like, is the jurisdiction of the courts over church affairs relating to property. To preserve the nomenclature of separation, and, I suggest, because of the radical individualism of religion in America, the courts in assuming jurisdiction have invented the dual entities doctrine, which presumes that there is a dichotomy between "temporal" and "spiritual" issues in the churches that represents the severability of polity from theology. But it is also a notion-though familiar in some religions and in classical philosophydenounced in the Gospel.90

\section{IV \\ LAW, Polity, AND Disunity: the sanction of schism}

The supposition that polity can be severed from theology and that therefore the courts can confine themselves to contests involving the "temporalities" of the church breaks down when the cases involving factionalism and schism in the churches are considered. Where a denomination divides into factions, where secession is threatened, where changes in confession or denominational affiliation are sought, where changes in polity are attempted-in any of these situations where the court is required to identify and interpret polity it is demonstrated that polity and theology cannot be separated. In these situations the question before the court is which of the disputants is entitled to the church property, and far more often than not the determination of that question provides a sanction for schism.

A. Factional Disputes within a Church

As between disputing factions within a church, the legal successor to the church property is said to be a question of which faction adheres to the original polity of the church.

Thus, where factionalism reaches the point of division or threat of secession in a church which has been of presbyterial or episcopal polity, the property goes to the denomination or to the faction still adhering to the discipline and government of the denomination. In Presbytery of Bismark v. Allen, a North Dakota congregation renounced the jurisdiction of the Presbyterian Church in the United States of America and voted unanimously to secede and the presbytery of which

90 See Romans 1:18-23, and cf. Colossians 1:15-20, Colossians 2:8-15, Psalm $19: 1-4$, I Corinthians 1:18-25, John 1:1-14. 
it had been a member successfully sued for possession of the property of the congregation:

Where a local religious society holding property is but a subordinate member of a larger organization with ultimate power in some supreme judiciary ... [property] is held in trust for the general church body and it cannot be used in contravention of the decisions of the supreme church judiciary. ${ }^{91}$

Similarly, Ohio provides by statute that property held by the brard of an endowment fund religious corporation created by a presbytery, synod, diocesan convention or other representative body of a religious denomination "shall be applied to the use and benefit of the proper denomination within this state."

Where there are factional disputes in a church with congregational polity, the majority of the congregation retain the property of the church, although in Virginia, where such a provision is incorporated in statute, the control of the property is subject to court approval. ${ }^{93}$ In a denomination with congregational polity, where there is schism, each congregation, by majority vote, decides the faction to which the congregation belongs, and the property follows the decision. ${ }^{94}$ Even where independent polity prevails, however, it may not be exercised in a manner which impairs the obligation of contract or alters the terms of a trust, and so where property has been given to a church of congregational polity and the donor has made the gift for the furtherance of particular doctrine or confession, the will of the majority faction departing from that confession may not defeat the duty to the donor. ${ }^{95}$

B. Change in Denomination or Confession

Where the substance of discord is the attempt to change denominational affiliation or to alter creed or confession of faith, the courts favor retention of church property by the original denomination or the adherents to the original confession. Even in churches of congregational polity this is generally the rule. It has been held that in a church of congregational polity, the majority is supreme only if faithful to its custom, usage, faith, and practice, and the majority may not divert property to another denomination whether or not the property is subject to an express trust. ${ }^{96}$

A century ago the law upheld, in New York, such a diversion. In Petty v. Tooker the court approved a change of denomination from Congregationalist to Presbyterian on the grounds that a religious corporation has no denominational character and that the trustees of the

0174 N.D. $400,413-14,22$ N.W.2d 625, 631-32 (1946).

92 OHIO Rev. CODE $\S 1715.12$ (1953).

93 VA. CODE tit. 57, $\$ 9$ (1950).

94 Bunnell v. Creacy, 266 S.W.2d 98 (Ky. Ct. App. 1954).

85 Finley v. Brent, 87 Va. 103, 12 S.E. 228 (1890).

08 Park v. Chaplin, 96 Iowa 55, 64 N.W. 674 (1895); Franke v. Mann, 106 Wis. 118, 81 N.W. 1014 (1900). 
corporation had power to effect a change of denomination. In that case the court read independent polity into the Religious Corporation Act:

The act for the incorporation of religious societies was obviously framed with a view to, and in accord with, that just and sound principle which lies at the basis of all our civic institutions, viz: that in every organized society, the controlling power should be in the hands of the majority. ${ }^{97}$

Petty has been interpreted as holding that the diversion of property could be "from the dissemination of the views of the persons acquiring it to that of any other view, whether religious or secular, which might be sanctioned and adopted by a voting majority of the congregation."98

This doctrine appears in muted form in cases in other jurisdictions, for example in an Indiana case in 1896, involving a bitter disagreement over doctrine within a Baptist church, the court indicated that where a religious corporation holds property for a church with defined theological doctrine, a change in confession can only be accomplished by unanimous vote of the members of the congregation. ${ }^{99}$

However, the rule today is contrary. In New York, the Petty formula was changed by statute providing that the trustees of a religious corporation should administer its property for the benefit of the corporation in accordance to the discipline, usages and rules of the denomination to which it belongs. ${ }^{100}$ The expulsion by the majority in a church of congregational polity of a minority who still adhere to the original faith does not affect the rights of the faithful minority to the church property. ${ }^{101}$ Coupled with this implied trust in favor of the original denomination and the propagation of the original confessional position, in cases involving change of denomination or confession, is the trust to effectuate the intention of donors of church property. In such a case, the Indiana court in Lamb v. Cain said that "however delicate and difficult it may be, it is the duty of the court to inquire whether the party accused of violating the trust is teaching a doctrine so far at variance with that intended as to defeat the objects of the trust."102

\section{The Care and Conservation of Schism}

Such decisions and statutes as these conserve division in the Church and sanction the further fragmentation of the Church into sects and denominations, frequently organized around a single issue.

Public policy, of course, reflecting congregational polity, considers that religious liberty and religious dissent are virtually the same thing

9721 N.Y. at 272,8 N.Y. Supp. at 272.

98 Isham v. Trustees, 63 How. Pr. 465 (N.Y. Sup. Ct. 1882).

99 Smith v. Pedigo, 145 Ind. 361, 44 N.E. 363 (1896).

100 N.Y. LAws 1875 , ch. $79, \S 4$. The same provision is now contained in N.Y. REL. CoRp. LaW $\S 5$.

101 See Smith v. Pedigo, supra note 99.

102129 Ind. 486, 510, 29 N.E. 646 (memorandum report) (1891). 
and are anyway essential to each other. Public policy does not condemn schism. It, on the contrary, encourages it.

At the same time, when factional disputes or attempts to change denomination or confession come before the courts, the law applies an implied trust doctrine which works to preserve the polity and doctrine of the original church or sect. And in the case where church property has been given for express confessional purposes, the trust provisions cannot generally be altered or defeated even though the will of the church is different and even if the trust purposes are not consistent with the contemporary needs and purposes of the church. This tends to prolong the survival of factionalism and divisiveness in the church.

The reunion of the Church-or appreciable and responsible advances toward reunion-will not come about unless the Church trusts the Gospel enough to resolve its internal differences without resort to law. The law, as seen in the schism cases, saves the churches from trusting the Gospel, and, in the name of dealing with "temporalities," interprets the confessional basis of those differences. Public policy is a two-edged sword-an inducement to schism and sectarianism, and a conservation of the divisions of the past around which denominations or sects were organized even where the reasons for division no longer apply or adherents of it are no longer on the scene.

\section{$\mathrm{V}$ \\ Law, Polity, and UnIon: \\ the churches in search of unity}

The churches are not ready for the reunion of the Church. Multiplication of sects and denominations is still the order of the times-in spite of the mergers between major denominations in the past several years and in spite of reunion negotiations and discussions of unity in progress and in prospect. The recalcitrant minorities which oppose and abstain from merger agreements usually regroup their strength and continue as a separate sect. The Church in America is amoebic.

The churches cannot blame the law for their disorder and disunity. But it can be argued that the law is not ready for the reunion of the Church either, nor even for approaches to reunion. And the argument here is just that: the law rests upon a policy which presumes disunity in the Church and which tends to conserve that disunity and abet dissidence. That, in its own way, is quite as much religious partisanship as the most conservative establishment of religion.

\section{A. Consolidation and Merger of Churches}

That the neutralism of the law toward religion is feigned is as much apparent when the law deals with cases involving merger and union of churches as in the schism cases. Indeed, the same doctrines govern the merger cases.

The law generally abstains from interference with ecumenical re- 
lations among churches where the formula is a federation of churches or denominations each of which retains its autonomy and property and joins in the federation merely for defined cooperative purposes. Such a federation is the National Lutheran Council, representing the voluntary collaboration of several separate Lutheran churches. ${ }^{103}$ And this is basis upon which some thirty-two Protestant and Eastern Orthodox denominations work together, more or less cumbersomely, I observe, in the National Council of Churches of Christ. ${ }^{104}$ And though the mere fraternization of different denominations in such federations may in the long run be a preparation for reunion of the Church, one recalls that good Anglican Bishop's observation that all the American churches are congregational in polity. For essentially the federative schemes are an application of that polity in which each constituent unit, here denominations rather than congregations, retains independence. In any case, it is not conclusive that federation is a prelude to reunion, it may even turn out to be contrary-wise, that is, the churches may be so little prepared for reunion that they comfortably accept piece-meal federation as a substitute for reunion.

The law has upheld amalgamations of local congregations, where churches continue without loss of their separate identities, each with their own property, united only by the ministry of the same pastor, but this, again, is hardly a viable alternative to the Church's reunion and is tied very much to immediate local conditions. ${ }^{105}$

Resort to the courts more often arises in cases where two general denominational bodies merge and protest of the merger is asserted by a dissident constituent congregation in one of the merging denominations. In such cases, either where the same or different polities and confessions are involved, the law tends to encourage division.

B. Merger and Common Polity or Confession

In the merger cases, the dual entities doctrine applies. The courts say that whether the law of a church permits union with another church is generally a purely ecclesiastical question not subject to civil review. ${ }^{106}$ But where churches are incorporated, mergers are subject to legislative authority and consent just as any other corporations. ${ }^{107}$ Ohio provides by statute for consolidation of religious corporations in certain instances where the consolidating corporations recognize the same ecclesiastical jurisdiction, government, order and discipline, where the trustees of the

103 SPERry 236. See MEAd, op. cit. supra note 6, at 132-33.

104 See Yearbook of American Churches for 1959 (Landis ed. 1958). The predecessor of the National Council of Churches was the Federal Council of Churches. See SPERrY 231-32.

105 Gladding v. St. Matthew's Church, 25 R.I. 628, 57 Atl. 860 (1904).

106 First Presbyterian Church v. First Cumberland Presbyterian Church, 245 Ill. 74, 91 N.E. 761 (1910).

107 Gladding v. St. Matthew's Church, supra note 105. 
corporations agree on the merger and where two-thirds of the members of each church ratify the consolidation according to their own laws. With strict conformance to these requirements, the new entity succeeds to the property of the churches consolidating. ${ }^{108}$ This seems to be mainly applicable to churches of congregational polity, but Ohio also provided for consolidation of religious corporations where connected, that is presbyterial or episcopal, polities prevail. ${ }^{109}$ Two or more congregations in the same locality in Ohio can also consolidate whether or not they are initially incorporated, if they are each self-governing, execute a written agreement to consolidate and in the consolidated corporation preserve their identity and common usages. ${ }^{110}$ Presumably the latter provision protects the duty to donors of the consolidating congregations.

Where the disposition of property is involved in a merger, judicial review may be invoked to safeguard the continuing use of property for purposes designated by express trust or by a trust by implication. Thus, in the absence of an express trust, where a church when originally endowed is subordinate to or connected with some ecclesiastical organization or particular form of church government it cannot renounce its faith or denominational affiliations or become independent or unite with another denomination and still retain the endowment. ${ }^{111}$ The Ohio statute governing the disposition of church property by trustees of a religious corporation in favor of the "proper denomination" represents the same rule. ${ }^{112}$

Probably the most extensive litigation on merger between denominations of the same polity and confession arose in connection with the union of the Presbyterian Church in the U.S.A. and the Cumberland Presbyterian Church. That merger was contested in nine jurisdictions by dissident groups in the Cumberland Church mainly on grounds that the two denominations had differing confessions. The union was upheld in all but two jurisdictions, the view of the majority being that, according to presbyterial polity, the decision of the General Assembly of the Cumberland Church that the two bodies had substantially the same doctrine was conclusive on the civil court. ${ }^{113}$ The merger was accomplished, but the dissidents reorganized themselves and continue to this day as the Cumberland Presbyterian Church. ${ }^{114}$ Merger spawned a new schism.

108 OHIO Rev. CODE $\S 1715.08$ (1953).

109 OHIo Rev. CODE $\$ \S 1715.21-22$ (1953).

110 OHIO Rev. CODE $\$ 1715.10$ (1953).

111 Roshi's Appeal, $69 \mathrm{~Pa} .462,8$ Am. Rep. 275 (1871); cf. Presbytery of

Bismark v. Allen, 74 N.D. 400, 22 N.W.2d 625 (1946).

112 OHIO Rev. CODE $\$ 1715.12$ (1953).

113 First Presbyterian Church v. First Cumberland Presbyterian Church, 245 Ill. 74, 91 N.E. 761 (1910); cf. Ramsey v. Hicks, 174 Ind. 428,91 N.E. 344 (1910), and Brown v. Clark, 102 Tex. 323, 116 S.W. 360 (1909).

114 MEAD, op. cit. supra note 6 , at 176-77. 


\section{Merger and Diverse Polity or Confession}

Generally the statutes do not specifically deal with consolidation where diverse polity or confession is involved, although in Ohio two or more denominations, though not necessarily incorporated and though not of the same confession, may unite, if the union is accomplished unanimously, and petition the court for an order to convey the property of the consolidating bodies, provided the original terms of a donor's grant are not violated. ${ }^{115}$ In a Texas case, Brown v. Clark, the court linked the approval of mergers between churches of different confessions to the form of polity of the denominations, suggesting not only that polity and confession are integral to each other but that such unions depended upon the authority of the government of a church to alter the confession of a church. ${ }^{\text {I16 }}$

But the most notorious merger case is that of Cadman Memorial Congregational Society of Brooklyn v, Kenyon, in New York, where a local congregation sought a declaratory judgment that the General Council of the Congregational Christian Churches had no authority to proceed with a merger with another denomination of different polity, namely, the Evangelical and Reformed Church, which has a presbyterial polity. Part of the judgment which Cadman sought was that such congregations as abstained from the merger would be the legal successors to the property possessed by the General Council worth over $\$ 60,000,000$. The court ruled that property in the hands of the General Council, a constellation of agencies through which local congregations cooperated for common purposes, were unrestricted funds in which this particular local congregation failed to show a direct interest that would be violated by the merger. And the court further held that the General Council had no authority to compel non-assenting congregations to join the union. Cadman could abstain if it wished, but it could not prevent assenting congregations from joining in the union. ${ }^{117}$

In the merger cases, as in the schism cases, the law tends to uphold the polity and confession of the original denomination, the law tends to conserve its position against modification, but at the same time fundamental public policy encourages dissidents to constitute themselves as "new" sects or denominations. Almost every merger case is also a schism case.

\section{VI}

Law, The Churches, and the Church: public policy v. the prospect of reunion

The accommodation of pluralism and freedom in American society

115 OHIO Rev. CODE $\$ 1715.09$ (1953).

116 Brown v. Clark, supra note 113.

117 Cadman Memorial Congregational Society of Brooklyn v. Kenyon, supra note 10 . 
consists not in the abolition of controversy, but, on the contrary, in the maturity and content of controversy under the rule of law. The approach of the churches to reunion threatens a great deal of controversy, not only within and among the several churches, but also within the whole of society, and also between the churches and society. Reunion may provoke as much controversy as Reformation. If that controversy is avoided, the law will grow static and obsolete; if that controversy is feared, the law will be corrupted by evasion; if that controversy is suppressed, the law will be subverted.

Just as the present policy of the law toward the churches, styled here as "multiple establishment," represents substantial departure from the doctrine of disestablishment of the early United States, just so that policy and its presumption of continued Christian disunity becomes antiquated insofar as the churches reunite.

The first and fundamental recognition in controversy about the law of church-state relations must be that public policy in America has never been neutralist toward the churches. Public policy was not neutral either in the theocracy of colonial New England or in the liberal establishment of the crown colonies. It was not neutral in the first amendment disestablishment, nor in the subsequent state disestablishments, but embodied a partisanship for independent polity, a preferment which survives today.

Part of the fiction of neutralism of the law toward the churches is the supposition that polity and theology are severable, that is, that polity concerns the handling of the temporal as opposed to spiritual affairs of the churches and that the government of the church is a pragmatic issue. Yet ecumenical conversations now taking place challenge the notion that polity can be severed from theology and join in the view indicated by Dr. Richard Niebuhr that the recovery of integrity and unity in the Church requires the constitution or reconstitution of polity in terms responsible to the content of the Gospel. In short, reunion of the Church contemplates an integral relationship of polity and theology which essentially and radically contradicts the polity preferred by, embodied in, and rationalized in the public policy of church-state relations in America. The theology of unity challenges the theology of dissent. The theology of unity threatens public policy which presupposes the theology of separatism.

But since there is, indeed, no neutralism in public policy, the question posed by the prospect of reunion becomes one of whether the law's bias should differ from that which it has been. Will any other bias imperil religious freedom?

There is apparently great apprehension that it would, and the spectre of theocratic government is trotted out by the debaters to defend the present partisanship of the law. Yet even in colonial America it was clear that theocratic government was not the only or necessary alterna- 
tive in public policy. Even in colonial America where the church had enough cohesiveness and unity to secure establishment, that establishment was not necessarily inconsistent with freedom for religious dissent and non-conformity. And, as has been noted, in other countries which are democracies today, establishment and religious freedom are compatible. Just as a multiplicity of political parties does not in itself guarantee political freedom, much less stability, civic maturity, or national unity, so also a multiplicity of religious sects is not an essential guarantee of freedom of religion. Mr. Madison-I suggest because of his own religious partisanship-was mistaken.

The only attempt of the present paper is to suggest that insofar as present public policy inhibits the reunion of the Church, it lies within the vocation and witness of the Church to contest those inhibitions, and further, that any serious quest for unity by the churches in America will bring the churches into increasing conflict with a public policy which favors separatism and conserves schism. As that conflict emerges, the law of church-state relations will surely be reshaped-perhaps even drastically reconstructed. Query whether the reunion of the Church will be substantial and essential enough to warrant a public policy of re-establishment of the Church in America? 